\title{
Seleção de sítios de oviposição pelo opilião bromelícola Bourguyia hamata (Opiliones: Gonyleptidae) em uma área de restinga no sudeste do Brasil
}

\author{
Francini Osses
}

\begin{abstract}
Resumo
A escolha do sítio de oviposição pode ter várias implicações no desenvolvimento da prole e na aptidão da fêmea. As fêmeas do opilião Bourguyia hamata exibem cuidado maternal e utilizam exclusivamente a bromélia Aechmea nudicaulis como sítio de oviposição na Ilha do Cardoso, SP. Neste estudo investigou-se se características arquiteturais de $A$. nudicaulis podem influenciar sua escolha como sítios de oviposição por B. hamata na restinga da Ilha do Cardoso, SP. Dados sobre a presença de desovas no interior das bromélias, o comprimento das rosetas (em forma tubular), o ângulo da inclinação das bromélias em relação ao solo e a quantidade de detritos acumulada no interior das bromélias foram obtidos ao longo de um transecto de $700 \mathrm{~m}$ entre fevereiro de 2005 a janeiro de 2006. Adicionalmente, foram usados dados coletados em 2001 sobre o volume de água no interior da roseta, assim como sobre a variação de umidade ao longo do dia no interior de bromélias grandes (30-32 mm) e pequenas (18-20 $\mathrm{mm})$ e também no ambiente externo. A freqüência de desovas foi maior em indivíduos com inclinações entre $90^{\circ}$ e $150^{\circ}$, para os quais a quantidade de detritos no interior da bromélia foi menor. Rosetas maiores foram mais usadas como sítio de oviposição por fêmeas de $B$. hamata. Além disso, bromélias maiores acumularam mais água no seu interior, de forma que a variação da umidade relativa foi menor dentro das bromélias grandes quando comparada com o ambiente externo. Fêmeas de B. hamata, além de escolherem apenas uma espécie de bromélia, conseguem acessar também características estruturais dos indivíduos de $A$. nudicaulis. As fêmeas ovipuseram predominantemente nos indivíduos que acumularam mais água e possuíam menos detritos nas rosetas, provavelmente porque essas características devem promover um microhabitat mais adequado para o desenvolvimento da prole.
\end{abstract}

Palavras-chave: interação animal-planta, Bromeliaceae, Aechmea nudicaulis, cuidado maternal, investimento parental, seleção de habitat, arquitetura da planta, estrutura do habitat, microhabitat \begin{tabular}{|l|}
\hline FICHA CATALOGRÁFICA \\
Elaborada pelo Sistema de Bibliotecas da UFU / \\
Setor de Catalogação e Classificação \\
Osses, Francini, 1979- \\
$\quad$ Seleção de sítio de oviposição pelo opilião \\
bromelícola Bourguyia hamata (Arachnida: opiliones) \\
em uma área de restinga no sudeste do Brasil / \\
Francini Osses. - Uberlândia, 2006. \\
35f. : il. \\
Orientador: Glauco Machado. \\
Dissertação (mestrado) - Universidade Federal de \\
Uberlândia, Progra-ma de Pós-Graduação em Ecologia \\
e Conservação de Recursos Naturais. \\
Inclui bibliografia. \\
$\quad$ 1. Aracnídeo - Teses. I. Machado, \\
Glauco. II. Universidade Federal de Uberlândia. \\
Programa de Pós-Graduação em Ecologia e \\
Conservação de Recursos Naturais. III. Título. \\
CDU: $595.43 \quad$ \\
\hline
\end{tabular} 